\title{
Determining Yttrium in Plutonium by Anion-Exchange X-Ray Fluorescence
}

\author{
Calvin J. Mariell \\ James M. Hansel
}

\section{DISCLAIMER}

\begin{abstract}
This report was prepared as an account of work sponsored by an agency of the United States Government. Neither the United States Government nor any agency thereof, nor any of their $\varepsilon_{\mu}$,ployees, makes anv , arranty, express or implied, or assumes any legal liability or responsibility for the "- -uracy, completeness, or usefulness of any information, apparatus, product, or process $A$ losed, or represents that its use would not infringe privately owned rights. Referellce nerein to any specific commercial product, process, or service by trade name, trademark, manufacturer, or otherwise does not necessarily constitute or imply its endorsement, recommendation, or favoring by the United States Government or any agency thereof. The views and opinions of authors expressed herein do not necessarily state or reflect those of the United States Government or any agency thereof.
\end{abstract}
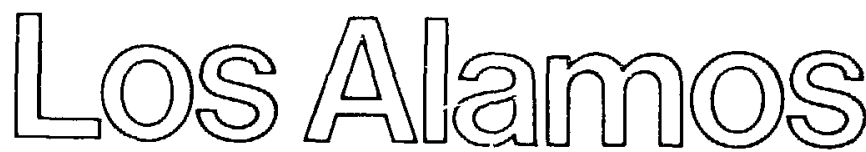


\title{
DETERMINING YTTRIUM IN PLUTONIUM BY ANION-EXCHANGE X-RAY FLUORESCENCE
}

by

\author{
Calvin J. Martell and James M. Hansel
}

\begin{abstract}
This report describes a method for determining yttrium in plutonium using an anionexchange separation and $x$-ray fluorescence. We add zirconium to the plutonium solution as an internal standard. We oxidize the plutonium to $\mathrm{Pu}+4$ and pass the solution through an anion-exchange col'amn with $8 \mathrm{M} \mathrm{HCl}$. The $\mathrm{Pu}+4$ sorbs to the resin and the yttrium and zirconium pass through completely. We evaporate the eluate solution containing the yttrium and zirconium and transfer it to a $10-\mathrm{ml}$ volumetric flask. We add a portion of this solution to an $\mathrm{x}$-ray cell and measure the $\mathrm{Ka} \mathrm{X}$-ray line for both yttrium and zirconium. The ratio of yttrium to zirconium is then compared with standards. This method has a precision of $0.84 \%$ relative standard deviation for yttrium over a concentration range of 0.5 to $3.5 \mathrm{mg}$ in a $10-\mathrm{ml}$ volume.
\end{abstract}

\section{INTRODUCTION}

Yttrium, a detector element added to plutonium, is used to measure neutron energies of underground nuclear explosions. To properly determine the strength of the nuclear device, we must know the concentration of the yttrium in plutonium.

It is difficult to accurately determine a small amount of yttrium in several hundred milligrams of plutonium. Therefore, we decided to separate the yttrium from line plutonium. The sample can then be handled more easily and safely with the plutonium removed.

To achieve the best precision possible, we add zirconium as an internal standard at the beginning of the analysis. Because it behaves like yttrium, zirconium is able to compensate for any changes that may occur in the sample during processing.

We transfer the eluate solution containing both yttrium and zirconium to a $10-\mathrm{ml}$ volumetric flask. We add a portion of this solution to an $x$-ray cell for the analysis. By working with solutions, we reduce the analysis time compared with the time needed to evaporate the solution to a small volume and then pipette it onto a resin paper disc.

\section{Equipment and Reagents}

In this work, we used the following equipment:

- Aluminum cell holder, 50-mm o.d.

- Columns, glass, ion exchange, 32 by $200 \mathrm{~mm}$

- Glass rod, bent and flattened on one end

- Heat lamps, infrared, red end, $250 \mathrm{~W}$

- Hot plate, 150 by $180 \mathrm{~mm}$

- Mylar film, 6- $\mu \mathrm{m}$ thick

- Sample cells, $x$-ray, Chemplex, plastic, series 1400 , 32-mm o.d.

- X-ray spectrograph; vacuum, Philips Electronics, Inc., LiF crystal; tungsten-target $x$-ray tube; and scintillation detector with associated electronic counting circuitry

We also used the following reagents:

- Hydrochloric acid, $12 \mathrm{M}, 8 \mathrm{M}$, and $0.1 \mathrm{M}$

- Hydrofluoric acid, 1.3M

- Ion-exchange resin, analytical grade anion-exchange resin (AG1X4), 50 to 100 mesh, chloride form, BioRad Laboratories 
- Nitric acid, 15.7M

- Yttrium solution, $0.500 \mathrm{mg} / \mathrm{ml}$

- Zirccnium solution, $0.500 \mathrm{mg} / \mathrm{ml}$

\section{SEPARATION OF YTTRIUM}

To dissolve the metal, we place a 1-g sample of plutonium in a covered $50-\mathrm{ml}$ beaker and add 5 to $10 \mathrm{ml}$ of $8 \mathrm{M} \mathrm{HCl}$. (If other plutonium compounds need to be dissolved, see our previous report.') We transfer the dissolved plutonium to an appropriate size volumetric flask and add $5 \mathrm{ml}$ of $15.7 \mathrm{M}$ HNO3 to the flask to help oxidize the $\mathrm{Pu}+3$ to $\mathrm{Pu}+4$. Then we add water to bring the plutonium solution to the flask mark.

The weight of the plutonium sample, the size of the volumetric flask, and the size of the aliquot all depend on the amount of yttrium in the plutonium. If we know the approximate yttrium concentration, we can arrange these three variables so that the amount of plutonium will provide sufficient yttrium to fall within the range of our standards. If the approximate yttrium concentration is not known, we take one small aliquot in case the concentration is high, and one large aliquot in case the yttrium concentration is low.

We add $2 \mathrm{ml}$ of the $0.500-\mathrm{mg} / \mathrm{ml}$ zirconium solution to a $20-\mathrm{ml}$ beaker. After having decided on the appropriate size of the aliquot, we add it to the $20-\mathrm{ml}$ beaker along with the internal standard, zirconium. To this solution, we add $0.5 \mathrm{ml}$ of $15.7 \mathrm{M} \mathrm{HNO} 3$ to ensure that all the Pu+3 has been converted to Pu+4. We heat the covered $20-\mathrm{ml}$ beaker with a heat lamp. The beaker is covered because there is effervescence at this point. (The effervescence can be greatly reduced by allowing the beaker to sit uncovered overnight.) When the effervescence has stopped, we rinse off the cover into the beaker with water and continue heating to incipient dryness. We add $2-3 \mathrm{ml}$ of $8 \mathrm{M} \mathrm{HCl}$ to the beaker and dissolve the sample, take it to incipient dryness once more, and redissolve the sample in $5-10 \mathrm{ml}$ of $8 \mathrm{M} \mathrm{HCl}$.

We fill the anion-exchange column with resin to within $2-3 \mathrm{~cm}$ of the top and condition the column with $8-10 \mathrm{ml}$ of $8 \mathrm{M} \mathrm{HCl}$ four times. We place a $20-\mathrm{ml}$ beaker under the column to catch the solution that will pass through and then add the plutonium solution to the top of the column by pouring the solution down a bent and flattened glass rod. After the plutonium solution has stopped flowing, we rinse the $20-\mathrm{ml}$ sample beaker with $2-3 \mathrm{ml}$ of $8 \mathrm{M} \mathrm{HCl}$ and a few drops of 1.3M HF and add this to the column. We continue to rinse with the $8 \mathrm{M}$ $\mathrm{HCl}$ until $15-20 \mathrm{ml}$ of solution has collected in the beaker under the column.

Passing the sample through the column allows the Pu+4 to sorb to the resin and allows the yttrium and zirconium to pass completely through. The flattened glass rod helps keep the plutonium near the top of the column so more resin is available to sorb the plutonium. This process achieves our separation. Then we need only start the evaporation of the yttrium and zirconium solution and recover the plutonium.

We evaporate our solution so that it will go into a $10-$ $\mathrm{ml}$ volumetric flask. We place an uncontaminated paper towel on the floor of the plutonium open-front box. Then working "hot" with one glove-covered hand, we pour the yttrium and zirconium solution into an $x$-ray cell held by our other glove-covered hand, which touches only uncontaminated objects. In this way, we transfer the essentially Pu-free but still contaminated solution to an $x$-ray cell, cover the cell with Mylar film, and then place it into our $x$-ray spectrograph with very little likelihood of contaminating our equipment.

We place the covered $x$-ray cell containing our sample solution in an aluminum cell holder, which also has a Mylar cover. The sample solution is excited by the tungsten-target $x$-ray tube. We measure, for $60 \mathrm{~s}$ each, the following $2 \theta$ settings:

\begin{tabular}{|c|c|}
\hline $2 \theta$ & Measurement \\
\hline 22.00 & Background 1 \\
\hline 22.4 & $\mathrm{Zr} \quad \mathrm{Ka}$ \\
\hline 23.0 & Background 2 \\
\hline 23.72 & $\mathbf{Y} \mathbf{K a}$ \\
\hline 24.50 & Background 3 \\
\hline
\end{tabular}

Figure 1 shows a plot of intensity vs $2 \theta$ for yttrium and zirconium after separation from a $250-\mathrm{g}$ sample of plutonium by anion exchange. The plot shows $1 \mathrm{mg}$ of zirconium and $2 \mathrm{mg}$ of yttrium. The intensity of yttrium is approximately $9000 \mathrm{c} / \mathrm{s}$.

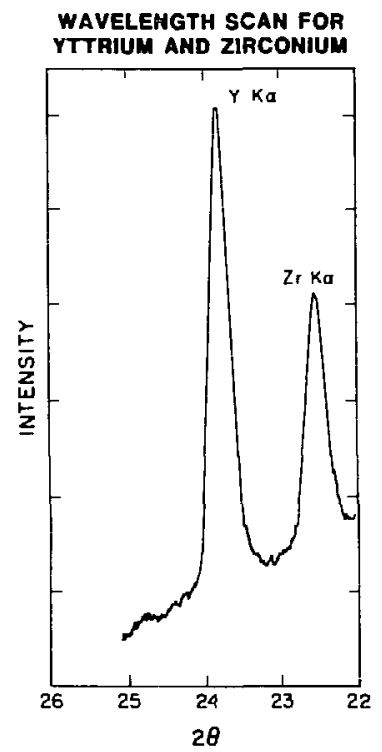

Fig. 1. Inlensity vs $2 \theta$ for $1 \mathrm{mg}$ zirconium and $2 \mathrm{mg}$ yttrium after their separation from a $250-\mathrm{g}$ semple of plutonium. 
We analyze the samples with the spectrographic conditions shown in the following table:

\section{X-Ray Operating Parameters}

\begin{tabular}{lll}
\hline X-ray tube & Tungsten & \\
Potential & $50 \mathrm{kV}$ & \\
Current & $30 \mathrm{~mA}$ & \\
Counter & Scintillation & $960 \mathrm{~V}$ \\
Analyzing crystal & $\mathrm{LiF}$ & \\
Counting time & $60 \mathrm{~s}$ &
\end{tabular}

\section{STANDARDS}

We prepared standards containing known amounts of yttrium and zirconium as listed below.

\begin{tabular}{|c|c|c|c|}
\hline $\begin{array}{c}\text { Standard } \\
\text { No. }\end{array}$ & $\begin{array}{c}\text { Yttrium } \\
\text { (mg) }\end{array}$ & $\begin{array}{l}\text { Zirconium } \\
\text { (mg) }\end{array}$ & $\begin{array}{c}\text { Plutonium } \\
\text { (mg) }\end{array}$ \\
\hline Y-1 & 0.0 & 1.00 & 100 \\
\hline Y-2 & 0.0 & 1.00 & 100 \\
\hline Y-3 & 1.0 & 1.00 & 100 \\
\hline$Y-4$ & 1.0 & 1.00 & 100 \\
\hline Y-5 & 3.0 & 1.00 & 100 \\
\hline Y-6 & 3.0 & 1.00 & 100 \\
\hline
\end{tabular}

We place $10 \mathrm{~g}$ of high-purity plutonium in a covered $250-\mathrm{ml}$ beaker and dissolve with $8 \mathrm{M} \mathrm{HCl}$ and a small amount of 1.3M HF. Next, we transfer the plutonium solution to a $100-\mathrm{ml}$ volumetric flask and add $5 \mathrm{ml}$ of 15.7M HNO3 to the flask to oxidize the plutonium to Pu+4.

Next, we pipette the appropriate amounts of the yttrium solution into each of six $20-\mathrm{ml}$ beakers. Then we add $1.0 \mathrm{mg}$ of the internal standard, zirconium, to each of the six beakers and pipette an appropriate amount of the high-purity plutonium solution, that is, $100 \mathrm{mg}$, into each of the beakers.

We analyze these standards as -described in the "Separation of Yttrium" section. Figure 2 shows a plot of intensity ratios $(\mathrm{Y} / \mathrm{Zr})$ vs concentration of yttrium. These data have a correlation coefficient for fit $=0.9998$.

\section{CaLCULATIONS}

To do the background corrections, we convert the intensities for all the readings to counts per second $(\mathrm{c} / \mathrm{s})$
STANDARD CURVE FOR YTTRIUM

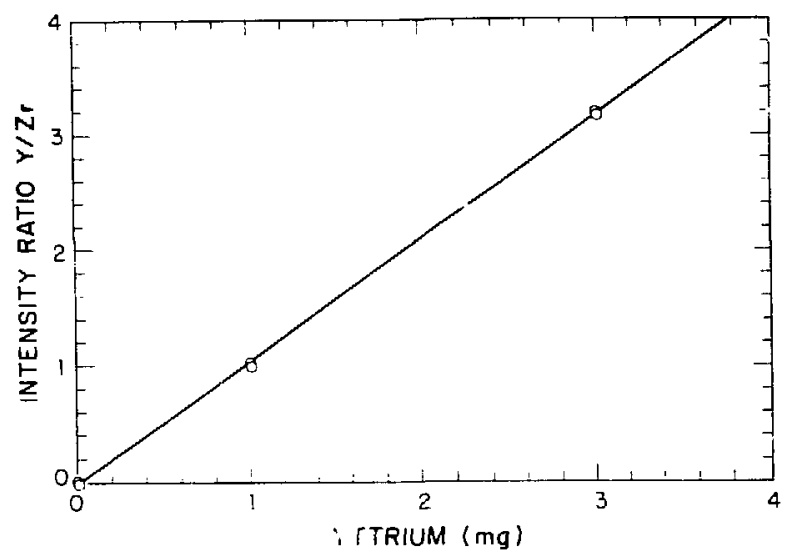

Fig. 2. Intensity vs concentration of yttrium.

and average the $\mathrm{c} / \mathrm{s}$ for background $I$ and background 2 and subtract this average from the zirconium $\mathrm{c} / \mathrm{s}$. Then we average background 2 and background 3 and subtract this average from the yttrium $\mathrm{c} / \mathrm{s}$. To obtain the $\mathrm{Y} / \mathrm{Zr}$ ratio, we divide the yttrium $\mathrm{c} / \mathrm{s}$ by tha zirconium c/s.

We do a least squares fit for the standards relating $\mathrm{Y} / \mathrm{Zr}$ ratios vs the yttrium concentrations. We use the coefficients for the equation representing this standard curve to calculate the concentration of yttrium in the analyzed samples.

\section{PRECISION}

To establish the precision of the method, we analyz samples repeatedly. Some of the samples were pure plutonium with known amounts of yttrium added. The results are sirown in Table $I$.

The average relative standard deviation for 0.5 to $3.5 \mathrm{mg}$ yttrium is 0.84 .

\begin{tabular}{ccc}
\hline TABLE I. Precision of Method & \\
\hline $\begin{array}{c}\text { Yttrium } \\
(\mathrm{mg})\end{array}$ & $\begin{array}{c}\text { Number of } \\
\text { Determinations }\end{array}$ & $\begin{array}{c}\text { Relative Standard } \\
\text { Deviation } \\
(\%)\end{array}$ \\
\cline { 3 - 4 } 0.5 & 6 & 1.13 \\
1.0 & 6 & 0.90 \\
1.5 & 6 & 0.67 \\
3.5 & 6 & 0.64 \\
\hline
\end{tabular}




\section{ACCURACY}

An official yttrium reference solution or compound was not available. We had $\mathrm{Y}_{2} \mathrm{O}_{3}$ assayed and analyzed. Using this well characterized material, we prepare a concentrated solution of yttrium $(12.5 \mathrm{mg} / \mathrm{ml})$ and use this to prepare the yttrium solution $(0.5 \mathrm{mg} / \mathrm{ml}) \mathrm{u}^{-n}-1$ in this work.

We add pure plutonium and zirconium to known amounts of yttrium at three levels and treat these solutions as described in the "Separation of Yttrium" section. The results are given in Table II.

The average recovery for the range 0.500 to $3.000 \mathrm{mg}$ vttrium is 100.1 .

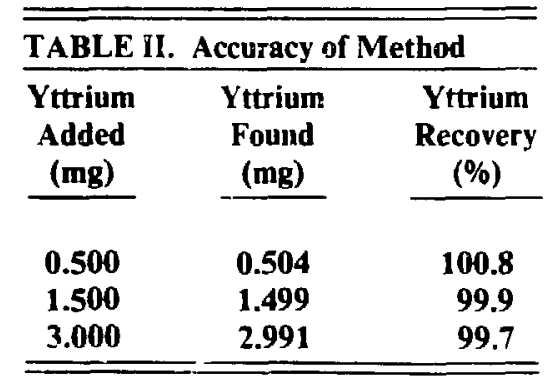

\section{DISCUSSION}

The precision of the $\mathrm{Y} / \mathrm{Zr}$ ratio is very go $\mathrm{d}$ while that for just yttrium is relatively poor. The zirconium behaves so much like yttrium that whatever causes the variations for yttrium also causes them for zirconium.

The amount of plutonium taken as a sample is one variable in this method. The relatively large ion-ex- change columns ( 32 by $200 \mathrm{~mm}$ ) in use permit as much as $500 \mathrm{mg}$ of plutonium to sorb on to the resin. At this level, approximately $1 \%$ of the plutonium passes through the resin along with the yttrium and the zirconium. At about $250 \mathrm{mg}$ of plutonium, somewhat less than $1 \%$ passes through the column.

When the sample size is between 200 and $10 \mathrm{mg}$ plutonium, the retention of plutonium is nearly $100 \%$. This figure assumes filling the column with resin to within $2-3 \mathrm{~cm}$ from the top and using the bent and flattened glass rod to keep the plutonium at the top of the column of resin.

Use of large sample sizes (250 to $500 \mathrm{mg}$ ) causes a deterioration of precision to approximately $5 \%$. The reason for this is not known, but we speculate that the plutonium on the column upsets the relationship between yttrium and zirconium so that they no longer behave identically.

When a relatively small sample size is used and nearly $100 \%$ of the plutonium has been removed, the standards and samples may be read on an energy dispersive $x$-ray unit. The $x$-ray tube target should be other than molybdenum (perhaps rhodium or silver) because the molybdenum $\mathrm{Ka}$ line will excite the zirconium only half as well as the yttrium line. This is because of the position of the absorption edges of these two elements.

\section{REFERENCE}

1. Calvin J. Martell and James M. Hansel, "Anion Exchange. X-Ray Fluorescence Determination of Uranium in Plutonium," Los Alamos National Laboratory report LA-9552 (February 1983). 